\title{
Conception of Local Wisdom Nangun Sad Kerthi Loka Bali in Character Education
}

\section{Putu Ronny Angga Mahendra}

Program Studi Pendidikan Pancasila dan Kewarganegaraan Fakultas Keguruan dan Ilmu Pendidikan Universitas Dwijendra

puturonny87@gmail.com

\section{Article History}

accepted 24/03/2021

approved 10/04/2021

published 20/04/2021

\begin{abstract}
Local wisdom is a wealth that can be used as a philosophy of learning in life that is in accordance with the way of life of the local community. One of the local wisdoms in Bali that supports and can be utilized in this case is Nangun Sad Kerthi Loka Bali, as an alternative to the current government to provide character education based on local wisdom. As one of the things set forth as the vision and mission of the Governor of Bali in carrying out the development of Balinese society. Development does not only include physical and non-physical aspects, in this case the quality of the Balinese people themselves. The characters that can be formed from government programs in the vision of Nangun Sad Kerthi Loka Bali are the spirit of nationality, love for the country, caring for the environment, caring socially, and responsibility. This will be a provision to keep abreast of global progress and still strengthen local wisdom as one's identity.

Keywords: Nangun Sad Kerthi Loka Bali, character building
\end{abstract}

\begin{abstract}
Abstrak
Kearifan lokal merupakan suatu kekayaan yang dapat dimanfaatkan sebagai suatu filosofi pembelajaran dalam kehidupan yang sesuai dengan tata cara hidup masyarakat setempat. Salah satu kearifan lokal di Bali yang mendukung dan dapat dimanfaatkan dalam hal ini adalah Nangun Sad Kerthi Loka Bali, sebagai salah satu alternatif pemerintah saat ini untuk memberikan pendidikan karakter dengan landasan kearifan lokal. Sebagai salah satu hal yang tertuang sebagai visi dan misi Gubernur Bali dalam melaksanakan pembangunan masyarakat bali. Pembangunan tidak hanya mencakup secara fisik dan juga non fisik dalam hal ini kualitas manusia Bali itu sendiri. Adapun karakter yang dapat dibentuk dari program pemerintah pada visi Nangun Sad Kerthi Loka Bali yaitu semangat kebangsaan, cinta tanah air, peduli lingkungan, peduli sosial, dan tanggung jawab. Hal ini akan menjadi suatu bekal untuk selalu bisa mengikuti kemajuan global dan tetap menguatkan kearifan lokal sebagai identitas diri.
\end{abstract}

Kata kunci: Nangun Sad Kerthi Loka Bali, pendidikan karakter

Social, Humanities, and Education Studies (SHEs): Conference Series https://jurnal.uns.ac.id/shes

p-ISSN 2620-9284

e-ISSN 2620-9292 


\section{PENDAHULUAN}

Pendidikan adalah usaha sadar dan terencana untuk mewujudkan suasana belajar dan proses pembelajaran agar peserta didik secara aktif mengembangkan potensi dirinya untuk memiliki kekuatan spiritual keagamaan, pengendalian diri, kepribadian, kecerdasan, akhlak mulia, serta ketrampilan yang diperlukan dirinya, masyarakat, bangsa, dan Negara (pasal 1 UU. Nomor 20 Tahun 2003 tentang Sistem Pendidikan Nasional). Pada era globalisasi ini, tidak dapat dipungkiri bahwa kejayaan dan kesejahteraan masyarakat dan negara bergantung pada sumbangan kreativitas berupa ide-ide baru, penemuan-penemuan baru, dan teknologi baru dari anggota masyarakat. Sumbangan kreativitas masyarakat terutama dalam Ilmu Pengetahuan dan Teknologi (IPTEK) sekarang ini mengalami perkembangan yang sangat cepat dan pesat, sehingga menuntut adanya peningkatan Sumber Daya Manusia (SDM) yang berkualitas dan bernalar tinggi. Kualitas SDM yang diutamakan adalah SDM yang unggul dalam IPTEK dan disertai dengan karakter mulia. Peningkatan SDM yang berkualitas dapat dicapai melalui pendidikan.

Demi mewujudkan tujuan-tujuan pendidikan yakni, meningkatkan pengetahuan individu, guna meningkatkan taraf hidup, mengembangkan kepribadian seseorang agara menjadi lebih baik, tidak cukup dengan pendidikan formal saja, dibutuhkan kolaborasi antara pendidikan formal dengan pendidikan non formal. Pendidikan non formal adalah pendidikan yang kegiatan belajar dan mengajarnya diadakan di luar sekolah untuk memenuhi kebutuhan pendidikan peserta didik tertentu untuk mendapatkan informasi, pengetahuan, latihan, dan bimbingan sehingga mampu bermanfaat bagi keluarga, masyarakat dan Negara. Perkembangan ilmu dan teknologi di era globalisasi sangat mempengaruhi perilaku anak bangsa yang semakin membuat terkikisnya nilai-nilai karakter. Kondisi ini Pembangunan sesungguhnya menjaga kelestarian alam dan kebersihan lingkungan serta mengeksistensikan pembangunan manusia baik manusia secara individu dan sebagai makhluk sosial dalam kehidupannya bersama untuk hidup saling melayani satu dengan yang lainnya. Degradasi karakter saat ini terdapat dan nampak pada semakin tertinggalnya kearifankearifan budaya lokal dan tergerus oleh kebudayaan luar yang semakin massif. Hal ini memiliki suatu dampa negatif bagi perkembangan generasi muda Indonesia, utamanya Bali sebagai daerah pariwisata yang terbuka dengan semua kedatangan orang luar dengan segala pengaruhnya. Selain itu pula, tidak sedikit generasi muda Bali yang kurang peduli dengan lingkungannya. Hal ini tentu menjadi suatu perhatian bagi seluruh masyarakat dan para pemangku kebijakan.

Pendidikan tidak hanya membangun karakter dan jati diri bangsa merupakan cita-cita luhur yang diwujudkan dalam penyelenggaraan pendidikan yang terarah dan berkelanjutan. Pendidikan tidak hanya mampu membangun kecerdasan (knowledge) tetapi juga mampu membangun karakter atau perilaku (character building). Pendidikan karakter yang berbasiskan kearifan lokal adalah pelaksanaan pendidikan yang mejunjung nilai-nilai budaya sehingga mampu membentuk karakter anak bangsa. Pendidikan karakter yang berbasis kearifan lokal yang diterapkan di Bali dapat dilihat dari arah kebijakan dan program pemerintah Provinsi Bali yaitu Nangun Sat Kerthi Loka Bali. Makna dari konsep ini adalah menjaga keharmonisan dan kesucian alam Bali beserta isinya mewujudkan kehidupan krama Bali yang sejahtera dan bahagia, sekala-niskala menuju kehidupan krama dan gumi Bali sesuai dengan prinsip Tri Sakti Bung Karno yaitu berdaulat secara politik, berdikari secara ekonomi, dan berkepribadian dalam kebudayaan. Dengan adanya kebijakan baru yang menjunjung tinggi kearifan lokal budaya Bali, diharapkan dapat membentuk karakter masyarakat Bali yang cinta akan budaya Bali.

Teori

Karakter dikembangkan melalui tahap pengetahuan (knowing), pelaksanaan (acting), dan kebiasaan (habit). Karakter tidak terbatas pada pengetahuan saja. 
Seseorang yang memiliki pengetahuan kebaikan belum tentu mampu bertindak sesuai dengan pengetahuannya, jika tidak terlatih (menjadi kebiasaan) untuk melakukan kebaikan tersebut. Karakter juga menjangkau wilayah emosi dan kebiasaan diri. Dengan demikian diperlukan tiga komponen karakter yang baik (components of good character) yaitu moral knowing (pengetahuan tentang moral), moral feeling (penguatan emosi) tentang moral, dan moral action atau perbuatan bermoral.

Menurut Rutland (2009:1) karakter berasal dari akar kata bahasa Latin yang berarti "dipahat". Karakter gabungan dari kebajikan dan nilai-nilai yang dipahat di dalam batu hidup tersebut, akan menyatakan nilai yang sebenarnya. Herman Kertajaya (2010:3) mengemukakan bahwa karakter adalah ciri khas yang dimiliki suatu benda atau individu. Orang yang memiliki karakter yang kuat, akan memiliki momentum untuk mencapai tujuan. Dengan demikian sudah selayaknya nilai-nilai karakter perlu dikembangkan pada diri anak sejak dini.

Istilah karakter berasal dari bahasa Yunani charassein yang berarti mengukir (Judiani, 2010). Membentuk karakter diibaratkan seperti mengukir batu permata atau permukaan besi yang keras. Kamus Bahasa Indonesia (2008) karakter didefinisikan sebagai sifat-sifat kejiwaan, akhlak, atau budi pekerti yang membedakan seseorang dari orang lain. Sedangkan menurut Philips (dalam Judiani, 2010) karakter adalah kumpulan tata nilai yang menuju pada suatu sistem, yang melandasi pemikiran, sikap, dan perilaku yang ditampilkan. Karakter tidak bisa diwariskan, karakter harus dibangun dan dikembangkan secara sadar hari demi hari dengan melalui suatu proses yang tidak instan. Karakter bukanlah sesuatu bawaan sejak lahir yang tidak dapat diubah lagi seperti halnya sidik jari.

Pendidikan karakter dimaknai sebagai pendidikan yang mengem-bangkan nilainilai karakter pada diri peserta didik sehingga mereka memiliki nilai dan karakter sebagai karakter dirinya, menerapkan nilai-nilai tersebut dalam kehidupan dirinya, sebagai anggota masyarakat dan warganegara yang religius, nasionalis, produktif, dan kreatif. Fungsi pendidikan karakter adalah : 1) pengembangan, 2) perbaikan, dan 3) penyaring. Pengembangan yakni pengembangan potensi peserta didik untuk menjadi pribadi yang berperilaku baik, terutama bagi peserta didik yang memiliki sikap dan perilaku yang mencerminkan karakter bangsa. Perbaikan, yakni memperkuat kiprah pendidikan nasional untuk bertanggung jawab dalam pengembangan potensi peserta didik yang lebih bermartabat. Penyaring, yaitu untuk menyeleksi budaya bangsa sendiri dan budaya bangsa lain yang tidak sesuai dengan nilai-nilai karakter yang bermartabat.

Pendidikan saat ini hanya mengedepankan penguasaan pada aspek keilmuan dan kecerdasan peserta didik. Hanya mengukur dari kriteria ketuntasan minimal (KKM), pendidikan sudah dianggap sudah memiliki keberhasilan. Pembentukan karakter dan nilai-nilai budaya bangsa di dalam diri peserta didik semakin tergurus dan terpinggirkan. Hal ini akan mempengaruhi eksistensi suatu bangsa dan negara, dari kepemilikan karakter dan budaya yang kuat. Era saat ini yang diperlukan pada generasi muda adalah yang berkarakter kuat, tetapi juga benar, positif dan konstruktif. Membentuk hal ini tidak diperlukan suatu feodalisme pendidik. Jika pendidik membuat peserta didik menjadi manutan, dengan nilai-nilai penting, tenggang rasa, dan tidak membantah, karakter peserta didik akan berkembang. Kepada peserta didik perlu diajarkan untuk berpikir sendiri. Dalam pelaksanaan pengembangan pendidikan berbasis karakter dan budaya bangsa, diperlukan berbagai masukan antara lain, menyangkut model-model pengembangan karakter dan budaya bangsa sebagai bagian yang tidak terpisahkan dari sistem pendidikan nasional.

Kearifan lokal adalah warisan masa lalu yang berasal dari leluhur, yang tidak hanya terdapat dalam sastra tradisional (sastra lisan penuturnya, tetapi terdapat dalam berbagai pandangan hidup, kesehatan, dan arsitektur. Kearifan lokal hanya akan abadi jika kearifan lokal terimplementasikan dalam kehidupan konkret sehari-hari sehingga 
mampu merespons dan menjawab arus zaman yang telah berubah. Menggali dan melestarikan berbagai unsur kearifan lokal, tradisi, dan pranata lokal, termasuk norma dan adat istidat yang bermanfaat dan dapat berfungsi efektif dalam pendidikan karakter. Kearifan lokal adalah pandangan hidup dan ilmu pengetahuan serta strategi kehidupan yang berwujud aktivitas yang ada dan dilakukan pada suatu masyarakat lokal dalam mencapai pemenuhan kebutuhan mereka dan mengatasi masalah mereka. Dalam istilah bahasa asing dapat juga dikonsepsikan sebagai suatu local wisdom atau local knowledge ataupun local genious sebagai suatu kecerdasan, pengetahuan, ataupun juga sebagai suatu kebijakan (Fajarini, 2014). Menggali dan melestarikan berbagai unsur kearifan lokal, tradisi, dan pranata lokal, termasuk norma dan adat istiadat yang bermanfaat dan berfungsi efektif dalam pendidikan karakter.

Karakter bangsa Indonesia adalah karakter yang dimiliki oleh warga Negara Indonesia berdasarkan tindakan yang dinilai sebagai suatu kebajikan berdasarkan nilai dan budaya yang berlaku di masyarakat dan bangsa Indonesia. Dengan konsep lain, pendidikan budaya dan karakter bangsa dimaknai sebagai suatu kepribadian diri warga negara. Pendidikan ini dimaknai sebagai pendidikan yang mengembangkan nilai-nilai budaya dan karakter sebagai karakter diri, sebagai masyarakat, dan warga negara yang religius, nasionalis, produktif dan kreatif.

\section{METODE}

Penelitian ini adalah penelitian kualitatif, yang termasuk pada kategori penelitian kepustakaan (library research). Penelitian dilakukan dengan mencari data dengan mengamati (observasi) secara mendalam untuk menemukan jawaban sementara sebelum penelitian ditindaklanjuti. Penelitian ini bersumberkan pada kepustakaan dengan sumber berupa jurnal, atau buku referensi. Pengumpulan data dilakukan dengan dokumentasi, yaitu jurnal yang berkaitan dengan Nangun Sat Kerthi Loka Bali dan juga pendidikan karakter. Metode analisis data yang digunakan yakni melalui tahapan reduksi data, display data, dan gambaran kesimpulan atau penarikan kesimpulan.

\section{Implementasi Konsep Sad Kertih}

\section{HASIL DAN PEMBAHASAN}

Selain konsep hidup yaitu Tri Hita Karana, dalam ajaran Hindu juga dikenal adanya Sad Kertih. Hal ini dirumuskan dalam lontar Purana yang terdiri dari : Atma Kertih, Samudra Kertih, Wana Kertih, Danu Kertih, Jagat Kertih, dan Jana Kertih. Atma Kertih berkaitan dengan kehidupan Sang Hyang Atma yang mesti dijaga kesuciannya dari Tri Guna. Penyucian atma dalam kehidupan umat Hindu Bali dengan melaksanakan penyucian atma orang yang meninggal dengan upacara Pitra Yadnya dari prosesi Ngaben sampai pada ngelinggihang Dewa Hyang (memasukan ke areal suci/ pura keluarga). Tujuan dari ini adalah agar atma dalam keadaan suci dan bersih. Atma kertih juga akan memiliki hubungan dengan Samudra Kertih yakni pelestarian samudra/laut. Dalam kebiasaan umat Hindu memanfaatkan laut sebagai tempat pengelukatan/pembersihan diri dari segala mala/kotoran di dalam diri manusia. Ini akan mungkin dilakukan ketika laut dalam keadaan suci dan bersih. Maka dengan demikian perlu menjaga dan sangat penting adanya kebersihan laut yang ada dan dimanfaatkan dalam kehidupan sehari-hari. Apabila laut rusak, pantai dterjang abrasi, pesisir yang dikapling untuk pembangunan hotel dan akomodasi wisata lainnya, maka akan sangat berdampak pada kehidupan rohani umat Hindu di Bali.

Dalam konsepsi Wana Kertih, sebuah upaya dalam melestarikan hutan. Banyaknya bangunan pura yang dibangun di tengah hutan (alas angker) adalah suatu cara leluhur dalam menjaga keangkeran hutan yang ada sehingga jauh dari perusakan hutan atau lingkungan sekitarnya. Hutan apabila mampu dijaga kelestariannya dan juga ekosistem di dalamnya akan mampu memenuhi kebutuhan hidup manusia. Perlakuan destruktif terhadap hutan Bali akan berdampak destruktif pula pada 
kehidupan manusia. Konsep Danu Kertih, adalah suatu upaya untuk menjaga kelestarian sumber-sumber air atawar di danau. Di setiap danau di Bali selalu ada pura sebagai simbol penjaga yang disebut dengan Pura Ulun Danu. Kondisi pelaksanaan Danu Kertih ini masih mengalami kondisi yang jauh dari maksimal dengan adanya sedimentasi danau-danau yang ada di Bali. Danau memiliki satu fungsi yang mirip dengan laut sebagai media dalam pelaksanaan upacara dan yadnya yang dilakukan oleh masyarakat Bali.

Kertih yang selanjutnya adalah Jagat Kertih, yaitu suatu upaya untuk melestarikan keharmonisan hubungan sosial di masyarakat. Jagat Kertih ini diterjemahkan dengan membangun konsep Desa Pekraman. Membangun keharmonisan yang dinamis dalam masyarakat Hindu di Bali lewat Desa Pekraman yang bercirikan adanya Tri Kahyangan. Kertih yang terakhir adalah Jana Kertih, suatu upaya yang membangun manusia yang memiliki kesadaran dalam merawat lingkungan hidup. Jika saja Sad Kertih ini diimplementasikan dalam upaya pencegahan dini terjadi bencana maka resiko terjadinya bencan dapat dikurangi atau diminimalkan.

\section{Pendidikan Karakter Berbasis Kearifan Lokal Nangun Sat Kerthi Loka Bali}

Kebijakan pemerintah Provinsi Bali saat ini "Nangun Sat Kerthi Loka Bali" yang tertuang dalam Visi Gubernur Bali, menunjukkan bahwa dengan menjaga kearifan budaya lokal. Dalam 18 nilai karakter yang dimunculkan oleh pemeritah, melalui Visi Nangun Sat Kerthi Loka Bali ini diharapkan generasi muda Bali memiliki karakter sebagai berikut :

1. Cinta Tanah Air/semangat kebangsaan

Hal ini menunjukkan seberapa besar kecintaan masyarakat Bali terhadap kebudayaannya dan sumber daya yang ada di Bali. Beberapa kebijakan pendukung yang dikeluarkan Pemerintah Provinsi Bali dalam memupuk karakter semangat kebangsaan dan cinta tanah air mulai dari hari penggunaan busana adat Bali, penyelenggaraan Bulan Bahasa Bali, Pemasaran dan Pemanfaatan Produk Pertanian, Perikanan, dan Industri Lokal Bali. Sebelum adanya kebijakan ini, banyak generasi muda yang merasa malu memakai pakaian adat/ busana adat Bali, penggunaan dan apresiasi Bahasa Bali. Bahasa Bali menjadi bahasa yang sulit untuk dipelajari dan tidak ada keinginan untuk dipelajari. Dengan adanya bulan Bahasa Bali, diharapkan kecintaan generasi muda Bali terhadap Bahasa Bali dapat ditingkatkan. Kegiatan-kegiatan lomba yang dilaksanakan penunjang kegiatan ini menjadi suatu stimulus pemicu bagi generasi muda untuk terus melestarikan Bahasa Bali.

2. Tanggung Jawab

Nilai karakter dapat ditumbuhkan melalui program pembatasan timbunan sampah plastik. Penggunaan plastik yang sekali pakai tentunya akan memberikan dampak negatif pada lingkungan. Menjadi sumber penyakit, banjir, kerusakan ekosistem sungai, laut, dan lain sebagainya. Tentunya kondisi ini menjadi tanggung jawab bersama. Kolaborasi masyarakat dengan pemerintah dengan pengurangan penggunaan plastik sekali pakai. Penggunaan tumbler menjadi salah satu alternatif ketika membawa minuman dalam berkegiatan. Apabila ini terus dapat dilakukan secara berkelanjutan maka akan memupuk karakter tanggung jawab sebagai masyarakat Bali.

3. Peduli lingkungan

Karakter ini merupakan salah satu karakter yang perlu dimiliki oleh segenap komponen masyarakat Bali khususnya para generasi muda. Karakter ini dapat ditumbuhkan melalui kebijakan pemerintah mengenai pembatasan timbulan sampah plastik sekali pakai. Dengan melakukan pembatasan tersebut, nantinya akan dapat menciptakan lingkungan Bali yang bersih dan asri, serta 
lingkungan yang bebas dari penyakit. Lingkungan yang bersih tidak akan bisa terwujud apabila yang menjalani hanya beberapa orang. Oleh karena itu, apabila seluruh masyarakat bali melaksanakan kebijakan ini, maka lamakelamaan akan menjadi suatu kebiasaan yang membentuk karakter masyarakat yang peduli lingkungan. Dengan begitu dapat menciptakan Bali yang indah dan lestari.

4. Peduli sosial

Peduli sosial dapat dilihat melalui program pemerintah yaitu Jaminan Kesehatan Nasional-krama Bali Sejahtera (JKN-KBS). Program ini ditujukan untuk menjamin kesehatan masyarakat Bali. Meskipun ini program pemerintah, namun dengan adanya program ini akan memupuk rasa kepedulian antara sesama masyarakat Bali. Program ini mengajarkan kepada kita bahwa pentingnya memperhatikan sesama manusia tanpa membedakan ras, suku, adat istiadat.

\section{SIMPULAN}

Dalam kebudayaan Bali, antara bhuana agung dan bhuana alit memiliki hubungan yangbersifat integralistik. Apapun yang terjadi di dalam bhuana agung, memiliki hubungan secara langsung dengan bhuana alit - begitu pula sebaliknya. Segala jenis aktivitas ritual yang dilakukan umat Hindu di Bali untuk memuliakan dan menjaga keseimbangan kosmik didasarkan pada munculnya kesadaran manusia yang terpusat pada alam (kosmos). Di sinilah ekosentrisme muncul. Segala ekspresi keagamaan manusia berorientasi pada kosmos, menyucikan gunung, danau, hutan dan laut. Secara fenomenologis, intensionalitas kesadaran manusia yang terpusat pada alam inilah membentuk kepercayaan dan kebudayaan masyarakat Bali. pemerintah

Berdasarkan pembahasan di atas, dapat disimpulkan bahwa, program

dengan Visi "Nangun Sat Kerthi Loka Bali"merupakan salah satu alternatif pemerintah untuk memberikan pendidikan karakter berbasis kearifan lokal. Program yang direncanakan oleh pemerintah yang terdiri dari hari penggunaan busana adat bali, pelaksanaan bulan bahasa bali, maupun penggunaan produk lokal bali menunjukkan bahwa sebagai masyarakat bali seharusnya bangga karena memiliki kekayaan alam, bahasa, adat istiadat Bali yang unik dan beragam. Adapun karakter yang dapat dibentuk dari program pemerintah pada Visi "Nangun Sat Kerthi Loka Bali" yaitu semangat kebangsaan, cinta tanah air, peduli lingkungan, peduli sosial, dan tanggung jawab.

\section{DAFTAR PUSTAKA}

Atmadja, Ida Bagus Oka Punia. (2007). Upedesa Tentang Ajaran-Ajaran Agama Hindu. Surabaya : Paramita

Candra Prasetya Dewi, Ni Putu. Pendidikan Karakter Berbasis Kearifan Lokal Melalui Nangun Sat Kerthi Loka Bali.Jurnal Widyacarya Volume 4 No. 2 September 2020.

Darwati, Mas \& Mahendra, Putu Ronny Angga. 2019. Efektivitas Pembelajaran PPKn Berbasis Teknohumanistik Dalam Pembentukan Karakter Siswa Kelas X Jasa Boga 2 di SMK Prshanti Nilayam Kuta Tahun Pelajaran 2017/2018. Singaraja: FHIS Universitas Pendidikan Ganesha.

Fajarini, Ulfah. (2014). Peranan Kearifan Lokal dalam Pendidikan Karakter. Sosio Didaktika. Vol. 1, No.2. Tersedia pada http://journal.uinjkt.ac.id/index.ph p/SOSIOFITK/article/view/1225/1093. Diakses pada 24 Februari 2020.

Jurdiani, Sri. (2010). Implementasi Pendidikan Karakter di Sekolah Dasar Melalui Penguatan Pelaksanaan Kurikulum. Jurnal Pendidikan dan Kebudayaan. Vol. 16, Edisi Khusus III. Tersedia pada https://media.neliti.com/media/pu blications/138571-none- 
Kertajaya, Hermawan. (2010). Grow with the Character: The Model Marketing. Jakarta: PT. Gramedia Pustaka Utama.

Mahendra, Putu Ronny Angga.(2018). Pembelajaran PPKn dalam Resonansi Kebangsaan dan Globalisasi. Jurnal Ilmiah IImu Sosial Vol. 4 No. 2. Singaraja : Universitas Pendidikan Ganesha.

Mahendra, Putu Ronny Angga \& Kartika, I Made. (2020). Memperkuat Kesadaran Bela Negara dengan Nilai-Nilai Pancasila dalam Perspektif Kekinian. Jurnal Pendidikan Kewarganegaraan Vol. 8 No. 3. Singaraja : Universitas Pendidikan Ganesha.

Mahendra, Putu Ronny Angga. (2014). Peran Pendidikan Kewarganegaraan dalam Melestarikan Budaya dan Pembentukan Karakter Bangsa. Jurnal Widyasrama Vol. 23 No. 1. Denpasar. Universitas Dwijendra.

Mahendra, Putu Ronny Angga. (2014).Peran Strategis PKn untuk Membangun Karakter Bagi Mahasiswa. Jurnal Widya Accarya Vol. 3 No. 1. Denpasar. Universitas Dwijendra.

Mustakim, Bagus. (2011). Pendidikan Karakter. Membangun Delapan Karakter Emas Menuju Indonesia Bermartabat. Yogyakarta: Samudera Biru

Paramita, I Gusti Agung. Bencana, Agama, dan Kearifan Lokal. Jurnal Dharmasmrti No. 18 Vol. I Mei (2018).

Rutland, Mark. 2009. Karakter Itu Penting. Terjemahan Ly Yen. Character Matters: Nine Essential Traits You Need To Succeed. Jakarta: Light Publishing.

Sugiyono. (2010). Metode Penelitian Pendidikan: pendekatan kuntitatif, kulitatif, dan $R \& D$. Bandung: Alfabeta.

UPDT. BPSMB Provinsi Bali. (2020). Nangun Sat Kerthi Loka Bali. Tersedia pada http://uptbpsmbbali.id/nangun-satkerthi-loka-bali/. Diakses pada 24 Februari 2020.

UU. No. 20 Tahun 2003 Tentang Sistem Pendidikan Nasional. 